\title{
A Multi-metric QoS Routing Algorithm with the Reinforcement Learning Method
}

\author{
Hiroyuki Une Member (Hiroshima Kokusai Gakuin University, Chiba University) \\ Fei Qian Member (Kanto Gakuin University) \\ Hironori Hirata Senior Member (Chiba University)
}

Keywords: Routing Algorithm, QoS, Reinforcement Learning, Q-Learning

QoS(Quality of Service) control is required by real-time communication services, such as audio and video streaming. We focus on the QoS routing algorithm which finds the routes satisfying the restrictions on the bandwidth and communication delay metrics. If violations are detected on current route, this algorithm has to choose another route from feasible routes.

In this paper, we propose the routing algorithm QQRA (Qlearning QoS Routing Algorithm). The node using QQRA selects the next hop by deterministic mode or probabilistic mode. When node $x$ using QQRA sends a packet to destination $t$, node $x$ selects the next hop node $y^{*}=$ $\arg \min _{y \in N_{x}} Q(t, y)$ in deterministic mode. On the other hand, node $x$ decides the next hop by the probabilites corresponding $Q(t, y)$ in probabilistic mode.

Node $x$ with QQRA exchanges the information of the communication delay $D_{x}(t, y)$ and the cost metric $C_{x}(t, y)$ between $x$ and destination $t$ via the next hop $y$. Node $x$ uses this information to update $Q(t, y) . Q(t, y)$ is updated by the following equation:

$$
\begin{aligned}
Q_{\text {new }, x}(t, y) & \leftarrow Q_{\text {old }, x}(t, y) \\
& +\eta\left\{r+Q_{y}(t)-Q_{\text {old }, x}(t, y)\right\},
\end{aligned}
$$

where $\eta$ is a learning rate. The reward $r$ is calculated as follows:

$$
r=r_{w}\left\{c_{w} \frac{C_{x}(t, y)}{C_{x t}}+d_{w} \frac{D_{x}(t, y)}{D_{x t}}+q_{w} \frac{b_{x y}}{l_{x y}}\right\}, \cdots
$$

where $C_{x t}$ and $D_{x t}$ are the constraints of cost and communication delay. $b_{x y}$ and $l_{x y}$ are the sum of packet length in the queue and the length of the queue of the link $(x, y) . c_{w}$, $d_{w}$, and $q_{w}$ are the weights for each metric. $r_{w}(=(0, \bar{Q}])$ is used as the parameter to normalize the reward.

We evaluate the effectiveness of QQRA by the simulations. Figure 1 shows the network topology. Each link has 3 [Mbps] bandwidth and 5.0 [ms] delay. As shown in Fig. 1, this network has five UDP sessions with constant bit rate. Figure 2 indicates that QQRA detects the growing of communication delay and alters the routes to satisfy the delay constraint $(500[\mathrm{~ms}])$ with deterministic mode. Furthermore
QQRA chooses the route satisfying cost constraint (5) as shown in Fig. 3.

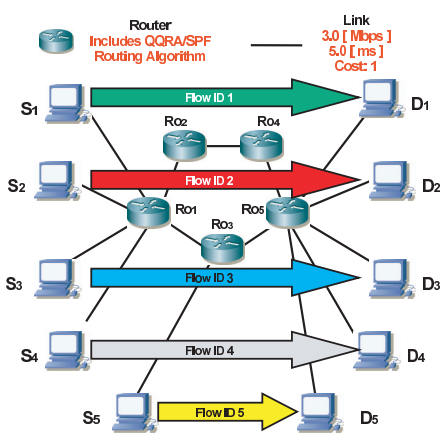

Fig. 1. Network topology

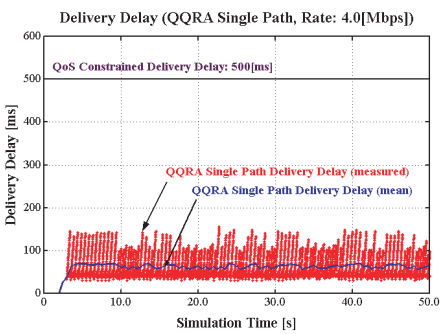

Fig. 2. Communication delay of Flow ID 1 (Total Input Rate: 4.0 [Mbps])

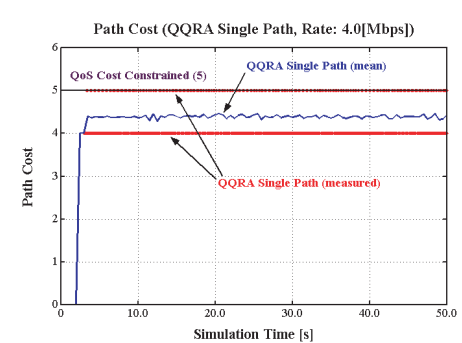

Fig. 3. Cost of route for Flow ID 1 (Total Input Rate: 4.0 [Mbps]) 


\title{
強化学習による複数のメトリックを考慮した QoS ルーティングアルゴリズム
}

\author{
正 員 鵜根 弘行*,** 正員 銭 飛*** \\ 上級会員 平田 廣則**
}

A Multi-metric QoS Routing Algorithm

with the Reinforcement Learning Method

Hiroyuki Une ${ }^{*, * *}$, Member, Fei Qian***, Member, Hironori Hirata**, Senior Member

Recently, there are numerous services, such as audio and video streaming, which are real-time communication services which guarantee bandwidth and low latency, called "QoS (Quality of Service)." To ensure the bandwidth and shorten the communication delay, it is required to solve the problem of finding paths which satisfy the QoS constraints made of two or more metrices, such as link costs and communication delay. However, this problem is shown as an NP-complete problem. We introduce a routing algorithm with a reinforcement learning scheme to obtain the paths which satisfy two or more constraints.

キーワード：ルーティングアルゴリズム, QoS, 強化学習, Q 学習

Keywords: Routing Algorithm, QoS, Reinforcement Learning, Q-Learning

\section{1. 研究背景}

近年, インターネットにおいて音声や動画を配信するサー ビスが増加している。これらのサービスは実時間通信であ ることが要求されるため, 一定の通信速度を保証するほか にも遅延や通信時間の変動（ジッタ）の抑制が必要となる。 その一方で，電子メールや FTP · HTTP などを利用した デー夕通信など，実時間性を求められないサービスも存在 する。もしこれらのサービスを利用している多数のユーザ が同時にデータの転送を行った場合，利用可能な通信帯域 を占有してしまい, 輻輳が発生する。それに伴い通信パケッ 卜の消失やジッタの増大が発生し, 実時間通信の品質が保 てなくなる。これを解決するため, ネットワークの通信带 域の確保ならびにトラフイックの優先順位を設定するなど

\footnotetext{
*広島国際学院大学

于 739-0321 広島市安芸区中野 6-20-1

Hiroshima Kokusai Gakuin University

6-20-1, Nakano, Aki-ku, Hiroshima, 739-0321

** 千葉大学

厂 263-8522 千葉市稲毛区弥生町 1-33

Chiba University

1-33, Yayoi-cho, Inage-ku, Chiba, 263-8522

*** 関東学院大学

⿳亠口冋 236-8501 横浜市金沢区六浦東 1-50-1

Kanto Gakuin University

1-50-1, Mutsuura-Higashi, Kanazawa-ku, Yokohama, 2368501
}

の, QoS (Quality of Service) 制御の重要性が高まって いる。

一般に QOS 制御には輻輳制御, 通信带域の予約, ジッタ の抑制，ならびにトラフィックの優先順位の設定などが含 まれる。これらを効率よく実現するために, 我々は以下の 要素が特に重要だと考える。

・QoS スケジューリングアルゴリズム

・ QoS ルーティングアルゴリズム

QoS スケジューリングアルゴリズムは，ルータで送出す るパケットの順序ならびにタイミングの制御を行う。重み付 けフェアスケジューリング (WFQ: Weighted Fair Queuing)(1) をはじめとするパケットスケジューリングアルゴリ ズムがそれにあたる。パケットスケジューリングアルゴリ ズムでは, トラフィックを通信遅延などの要求 (QoS 要求) に応じて複数のクラスに分類する。そして要求に応じた優 先度を各クラスに与え, パケットの送出制御を行う。特に WFQ では優先度の高いトラフィックが回線を占有しない よう，各トラフィックに最大遅延時間を設定することが可 能である。しかしながら, QoS スケジューリングアルゴリ ズムはネットワーク全体の遅延特性の変動に対応できない という問題がある(2)。そのため, QoS 要求を満たす経路の 探索が必要となる。

QoS ルーティングアルゴリズムは，トラフィックの品質 要求に基づく制約（QoS 制約）を満たす経路の探索を行う。 ここで複数の品質要求, 例えば最大通信遅延と最小通信带 
域の両方の制約を満たす経路を見つけることは, 複数の制 約条件を扱う QoS ルーティング問題に相当する。しかし, このような QoS ルーティング問題は NP 完全であることが 証明されている ${ }^{(3)}$ 。さらに，インターネットのバックボー ン（コアネットワーク）におけるトラフィックの変動には長 期依存性，あるいは自己相似性があるといわれている。長 期依存性が存在するネットワークでは，トラフィックの独 立性が成立しない(4)。したがって，待ち行列理論を用いた 古典的なモデルを用いた経路探索は，トラフィックの独立 性が成り立っていることを前提としているために適切では ないと考えられる。そのため, ネットワークの特性の変化 によって発生した QoS 制約違反に対して動的に対応するこ とのできる新しい手法が提案されている。

Chen と Nahrstedt は複数の制約条件を扱う QoS ルー ティング問題を，大域的な情報を使用せずに解く分散型ルー ティングアルゴリズムを提案した ${ }^{(5)}$ 。このアルゴリズムを 使用するノード†は，プローブと呼ばれるメッセージをお互 いに交換する。プローブには送信元 $s$ と宛先 $t$, コネクショ ン識別子 cid, および QoS 制約条件 Q o S が記録されてい る。プローブを受け取ったノード $i$ は, このプローブがどこ から届いたかを $p_{i}($ cid $)$ に記録する。そして QoS 制約条件 を満たすリンクによって接続されている全てのノードに対 してプローブを送信（フラッディング）する。これらの操 作は幅優先探索胡に相当するため, 最終的にプローブは宛 先 $t$ に到着する。この時点で各ノードに記録された $p_{i}($ cid $)$ をノード $t$ から逆順にたどることで，コネクション cid が 要求する QoS 制約条件を満たす経路が求まる。しかしなが ら Chen と Nahrstedtのアルゴリズムは, リンクの通信遅 延・利用可能な帯域およびコストが既知であることを前提 としている。そのため, トラフイックの変化による QoS 制 約違反の検出ならびに代替経路の確保は考慮されていない。

Peng はQoS ルーティング問題を，与えられた制約を満 たす辺素な（共通するリンクが存在しない）経路を発見す る問題に帰着させたアルゴリズムを複数提案した ${ }^{(6)}$ 。その 中の一つである Lag-2DP はラグランジュ緩和法により, 送 信ノード $s$ と受信ノード $t$ をつなぐ経路の中から以下の制 約を満たす二つの辺素な経路 $P_{1}, P_{2}$ を発見する。

$$
\begin{aligned}
& \sum_{i=1}^{2} D\left(P_{i}\right) \leq\left(1+\frac{1}{k}\right) D \ldots \ldots \ldots \ldots \ldots \ldots \ldots \ldots \ldots \ldots \ldots \\
& \sum_{i=1}^{2} C\left(P_{i}\right) \leq(1+k) O P T \ldots \ldots \ldots \ldots \ldots \ldots
\end{aligned}
$$

†本稿では PC やルータなど, データパケットを送受信する機器の 総称として「ノード」を用いる。

†幅優先探索とはグラフや木の探索を行う際, 開始ノードの隣接ノー ド集合を最初に探索し，次にこれらの隣接ノードに隣接する集合，さ らに隣接するノード集合へと探索範囲を拡げていくアルゴリズムであ る。Chen らのアルゴリズム (5) において, 宛先 $t$ 以外のノードはプ ローブを受信したら自分自身の隣接ノード集合にフラッディングを行 う。ネットワークをグラフとして考えた場合, フラッディングは隣接 ノードの探索に相当するため, 宛先ノード $t$ の幅優先探索を行ってい るとみなすことができる。
ここで $D\left(P_{i}\right), C\left(P_{i}\right)$ はそれぞれ経路 $P_{i}$ の通信遅延なら びにコストを表す。 $D$ は経路の遅延制約, OPT はノード $s, t$ 間を結ぶ経路の最小コストを示す。 $k$ は解の精度に関す るパラメータである。Lag-2DP はラグランジュ緩和法を用 いているため, 得られた解がすべて QoS 制約条件を満たす 保証はない。しかし 3 本以上の辺素な経路の発見にもその まま利用できるため, 与えられた QoS 制約を満たす複数の 経路を求めることが可能になる。

Peng の提案したアルゴリズムは, いずれもトラフィック の流量やネットワークの遅延, およびコストのパラメータ などが事前に与えられていることが前提である。そのため Chen のアルゴリズムと同様, QoS 制約違反の検出および 代替経路の計算は考慮されていない。

Chen と Nahrstedt のアルゴリズムおよび Peng のアル ゴリズム自体は，ネットワークのノード数ならびにリンク 数に対する多項式時間のオーダーで実行可能である。その ため QoS 制約違反の検知と同時に代替経路を動的に計算す る場合のコストはそれほど大きくないと考えられる。しか しそのためにはネットワーク全体の状態を監視し, 代替経 路の計算を行う管理ノードの存在が前提となる。

本研究では, 複数メトリックを考慮した分散型 QoS ルー ティングアルゴリズム QQRA（Q-learning QoS Routing Algorithm）を提案する。QQRA は経路の検出に $\mathrm{Q}$ 学習 (Q-Learning) (7) を用いることで, 遅延特性の変動に対応 した動的ルーティングを行う。具体的には測定した通信遅 延やリンクのコストに基づいて経路を決定する。そのため QoS 制約違反を検知した場合, QQRA はただちに QoS 制 約を満たす別の経路を探索, 切り替えを行うことが可能で ある。QQRAは隣接ノードとの間で通信遅延やコストに関 する情報を交換するが，ネットワークのトポロジーならび に各リンクを流れるトラフィックの流量に関する完全な情 報を必要としない。これはネットワークを監視するために 特別な仕組みを用意する必要がないことを意味する。

本稿の構成を以下に示す。 2 章では QoS ルーティング問 題について説明する。3 章では Q-Learning の理論, なら びにルーティングアルゴリズムへの応用について述べる。

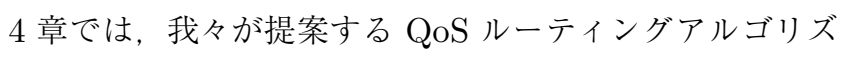
ム QQRA について解説する。5 章ではネットワークシミュ レータによる実験結果を元に, 提案するルーティングアル ゴリズムの有効性を検証し，6章でまとめを行う。

\section{QoS ルーティング問題}

QoS ルーティング問題は, 送信元から宛先までの QoS 要 求を満たす複数の経路の中から配送に利用する経路を決定 することである ${ }^{(8)}$ 。QoS ルーティング問題における基本的 な $\mathrm{QOS}$ 要求として, 以下の 2 つが考えられる。

QoS 最適条件 指定したメトリックが最適となる経路を 要求する

QoS 制約条件＼cjkstart指定したメトリックが条件を満たす経路 を要求する 
QoS ルーティング問題を扱うために，以下の記号を導入 する。まず，対象となるネットワークのトポロジーを双方 向グラフ $G=(N, L)$ として表現する。ここで $N$ はネット ワーク上の全ノード集合を表す。ノードの総数は $|N|$ と表 記する。Lはネットワーク上のリンクの集合を表す。リン クの総数は $|L|$ と表記する。個々のリンク，例えばノード $i, j(\in N)$ 間のリンクは $(i, j)$ と表記する。また, ノード $x \in N$ の隣接ノード集合を表す記号として $N_{x}$ を用いる。 リンク $(i, j)$ に割り当てられたメトリックは $m_{i j}$ と表記す る。複数のメトリックを使用する場合は, ベクタ表現 $\boldsymbol{m}_{i j}$ を用いる。

ノード $s, t \in N$ 間の経路は, 経路を構成するリンクの 並び $(s, i),(i, j), \cdots,(l, t)$ として表す。ノード $s$ と $t$ の間 に複数の経路がある場合, それらの集合を $P t_{s t}$ と表す。ま た, $P t_{s t}$ の $k$ 番目の経路を $p t_{s t}^{k}$ とする。QoS ルーティン グを行う場合, $p t_{s t}^{k}$ の経路メトリック $m\left(p t_{s t}^{k}\right)$ を考慮する 必要がある。複数のメトリックを用いる場合は, ベク夕表 現 $\boldsymbol{m}\left(p t_{s t}^{k}\right)$ を使う。

$\langle\mathbf{2} \cdot \mathbf{1}\rangle$ メトリックの分類 Q Q OS で取り扱うリンクメ トリックには帯域幅, 遅延, ジッタ, コスト, 信頼性, 損失 率などが挙げられる。それぞれのメトリックは，次のよう に分類される(5) (8)。

加算性メトリック： $p t_{s t}^{k}$ の経路メトリックが $(3)$ 式の様 に, 経路中のリンクのリンクメトリックの和として表現 されるメトリック。遅延, ジッ夕, コストが該当する。

$$
\begin{aligned}
m\left(p t_{s t}^{k}\right) & =m_{s i}+m_{i j}+\cdots+m_{l t} \\
& =\sum_{(i, j) \in p t_{s t}^{k}} m_{i j} \cdots \cdots \cdots
\end{aligned}
$$

乗算性メトリック： $p t_{s t}^{k}$ の経路メトリックが $(4)$ 式の様 に, 経路中のリンクのリンクメトリックの積として表現 されるメトリック。信頼性や損失率が該当する。

$$
\begin{aligned}
m\left(p t_{s t}^{k}\right) & =m_{s i} \cdot m_{i j} \cdots m_{l t} \\
& =\prod_{(i, j) \in p t_{s t}^{k}} m_{i j} \cdots
\end{aligned}
$$

凹凸性メトリック： $p t_{s t}^{k}$ の経路メトリックが $(5)$ 式の様 に, 経路中のリンクのリンクメトリックの最小值として 表現されるメトリック。带域幅が該当する。

$$
\begin{aligned}
m\left(p t_{s t}^{k}\right) & =\min \left\{m_{s i}, m_{i j}, \cdots m_{l t}\right\} \\
& =\min _{(i, j) \in p t_{s t}^{k}}\left\{m_{i j}\right\} \cdots \cdots
\end{aligned}
$$

〈2·2〉 QoS 制約条件 QoS 制約条件において, メト リック $m$ と要求される值 $r$ との関係式を $(6)$ 式で表現する。

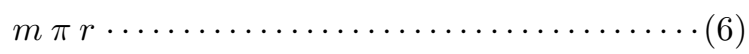

ここで $\pi$ は関係演算子 $(\in\{<, \leq, \geq\})$ である。同様に $n$ 個のメトリック $\left(m_{1}, \cdots, m_{n}\right)$ と，各メトリックに対する 要求 $\left(r_{1}, \cdots, r_{n}\right)$ との関係集合 $R$ を $(7)$ 式で表現する。

$$
R=\left\{\left(m_{1} \pi_{1} r_{1}\right), \cdots,\left(m_{n} \pi_{n} r_{n}\right)\right\}
$$

ここで $\pi_{j} \in\{<, \leq, \geq\} \quad(j=1, \cdots, n)$ である。

$\langle 2 \cdot 3\rangle$ 本研究で扱う QoS ルーティング問題本研究 では複数の制約を持つ QoS ルーティング問題として, コス トメトリックと遅延メトリックに関する 2 つの QoS 制約 条件を同時に満たす経路を求める問題を扱う。本来ならば QoS 最適経路を求めるべきであるが, NP 完全問題である ために経路を計算する時間が増大する。加えて遅延やジッ 夕など実数值で表現されるメトリックを用いた場合に最適 経路が二つ以上存在することは稀であると考えられる。そ のため負荷分散の観点からも，ルーティング問題を上記の 通り設定した。

まず, リンク $(i, j)$ のコストメトリックを $\boldsymbol{m}_{i j}=\left(c_{i j}, d_{i j}\right)$ と表記する。ここで $c_{i j}, d_{i j}$ はそれぞれリンク $(i, j)$ のコス トメトリックと遅延メトリックを表す。 $c_{i j}$ は OSPF ${ }^{(9)}$ な どで用いられているのと同様, リンクに与えられた重み係 数を表す。遅延メトリック $d_{i j}$ は以下の要素の実測值から 構成される。

キューイング遅延: パケットがノードの出力キューから 送信されるまでの待ち時間

シリアル化遅延：パケットをリンクに送信する際に発生 する遅延

リンク遅延: パケットが送出されてから隣接ノードに到 達するまでの遅延（リンクの距離に依存する）

前節で述べた通り，コストメトリックおよび遅延メトリッ クは加算性メトリックである。したがって経路 $p t_{s t}^{k}$ の経路 メトリックは次式で表現される。

$$
\begin{aligned}
\boldsymbol{m}\left(p t_{s t}^{k}\right) & =\boldsymbol{m}_{s i}+\boldsymbol{m}_{i j}+\cdots \boldsymbol{m}_{l t} \\
& =\sum_{(i, j) \in p t_{s t}^{k}} \boldsymbol{m}_{i j} \\
& \triangleq\left(\sum_{(i, j) \in p t_{s t}^{k}} c_{i j}, \sum_{(i, j) \in p t_{s t}^{k}} d_{i j}\right) \ldots \ldots
\end{aligned}
$$

ノード $s, t$ 間のコスト制約（最大コスト）を $C_{s t}, \quad$ 遅延 制約（最大遅延）を $D_{s t}$ とすると, 経路 $p t_{s t}^{k}$ の QoS 制約 条件 $\boldsymbol{R}_{s t}$ は次式で表すことができる。

$$
\boldsymbol{R}_{s t} \triangleq\left(\sum_{(i, j) \in p t_{s t}^{k}} c_{i j} \leq C_{s t}, \sum_{(i, j) \in p t_{s t}^{k}} d_{i j} \leq D_{s t}\right)
$$

以上より， $p t_{s t}^{k}$ を配送経路として利用するには，(10)(11) 式の両方を満たす必要がある。

$$
\begin{gathered}
\sum_{(i, j) \in p t_{s t}^{k} c_{i j}}=c_{s i}+c_{i j}+\cdots+c_{l t} \leq C_{s t} \cdots \\
\sum_{(i, j) \in p t_{s t}^{k}} d_{i j}=d_{s i}+d_{i j}+\cdots+d_{l t} \leq D_{s t} \cdots
\end{gathered}
$$




\section{Q-Learning}

〈3・1〉 Q-Learning の概要 Q-Learning ${ }^{(7)}$ はエー ジェントの行動を Q 值 (行動価值関数) として評価し, 方策 オフ型 TD (Temporal Differences) 制御を行うことで行動 を決定する, 強化学習の手法の 1 つである(10)。Q-Learning に使われる記号を以下に示す。

$$
\begin{aligned}
& s_{t} \text { ：時刻 } t \text { での環境の状態を表す。 } \\
& a_{t}: \quad \text { 時刻 } t \text { での行動を示す。 } \\
& A_{t}\left(s_{t}\right) \text { ：時刻 } t \text {, 状態 } s_{t} \text { において可能な行動の集合 } \\
& \text { を表す。 } \\
& a_{t}^{*}: \quad A_{t}\left(s_{t}\right) \text { の中で最適な行動を表す。 } \\
& Q\left(s_{t}, a_{t}\right) \text { : 状態 } s_{t} \text { において, 行動 } a_{t} \text { の価值を表す行動 } \\
& \text { 価値関数 }(\mathrm{Q} \text { 值) を表す。值域は }[0, \bar{Q}] （ \bar{Q} \\
& \text { は価值の上限）である。本研究ではこの值 } \\
& \text { が小さいほど， } a_{t} \text { はよい行動であることを } \\
& \text { 意味する。 } \\
& r_{t} \text { ：時刻 } t \text { に得られた報酬を表す。本研究では } \\
& \text { この值が小さいほどよい結果を意味する。 } \\
& \pi\left(s_{t}\right): \quad \text { エージェントが状態 } s_{t} \text { において行う方策 (行 } \\
& \text { 動）を表す。 } \\
& Q_{\text {new }}\left(s_{t}, a_{t}\right) \\
& \leftarrow Q_{\text {old }}\left(s_{t}, a_{t}\right) \\
& +\eta\left\{r_{t}+\gamma Q\left(s_{t+1}, a_{t+1}^{*}\right)-Q_{o l d}\left(s_{t}, a_{t}\right)\right\} \cdots
\end{aligned}
$$

(12) 式中, $Q\left(s_{t+1}, a_{t+1}^{*}\right)$ は行動 $a_{t}$ によって遷移した状 態 $s_{t+1}$ において, 最適な行動 $a_{t+1}^{*}$ を行った場合の $\mathrm{Q}$ 值を 表す。 $Q\left(s_{t}, a_{t}\right)$ の定義より, $Q\left(s_{t+1}, a_{t+1}^{*}\right)$ は以下の式で 求められる。

$$
Q\left(s_{t+1}, a_{t+1}^{*}\right)=\min _{a \in A_{t+1}\left(s_{t+1}\right)} Q\left(s_{t+1}, a\right) \cdots
$$

また， $\gamma \in[0,1]$ は割引率を表すパラメータである。こ れは次の状態において最適な行動を行った場合の $\mathrm{Q}$ 值 $Q\left(s_{t+1}, a_{t+1}^{*}\right)$ が学習に与える影響を示す。 $\eta \in[0,1]$ は 学習率を表す。 $\eta$ の值が大きいほど, Q 值の変化が大きく なる。

エージェントは Q 值を元に自身の方策を (14) 式に基づ いて決定する。

$$
\pi\left(s_{t}\right)=\arg \min _{a \in A_{t}\left(s_{t}\right)} Q\left(s_{t}, a\right) \cdots \cdots \cdots \cdots \cdots
$$

ここで $\arg \min$ は，与えられた関数の值を最小にする引数 の值を求める関数である。つまり (14) 式は状態 $s_{t}$ におい て， $Q\left(s_{t}, a\right)$ が最小となる行動 $a^{*} \in A_{t}\left(s_{t}\right)$ を方策として 選択することを意味する。

〈3・2〉 ルーティングへの応用 Q-Learning を利用し たルーティングアルゴリズムとして, Q-Routing (Littman,
Boyan) (11) が挙げられる。Q-Routing では, ノード $x$ か ら隣接ノード $y$ を経由して宛先ノード $t$ に到達するまでの 推定時間 $Q_{x}(t, y)\left(y \in N_{x}\right)$ を $\mathrm{Q}$ 值として用いる。この 時 $Q\left(s_{t+1}, a_{t+1}\right)$ に相当するのはノード $y$ の $\mathrm{Q}$ 值 $Q_{y}(t, z)$ $\left(z \in N_{y}\right)$ である。ノード $x$ は次式で表される方策 $\pi_{x}\left(t, y^{*}\right)$ を用いてネクストホップ（転送先ノード） $y^{*}$ を決定する。

$$
\pi_{x}\left(t, y^{*}\right)=\arg \min _{y \in N_{x}} Q_{y}(t, y)
$$

Q-Routing における報酬 $r$ は, ノード $x$ のシリアル化遅 延とリンク遅延, およびネクストホップ $y$ でのキューイン グ遅延の和として与えられる。ノード $x$ は報酬 $r$ を元に, 次式を用いて Q 值を更新する。

$$
\begin{aligned}
& Q_{\text {new }, x}(t, y) \leftarrow Q_{\text {old }, x}(t, y) \\
& +\eta\left\{r+Q_{y}(t)-Q_{\text {old }, x}(t, y)\right\} \cdots \\
& Q_{y}(t)=\min _{z \in N_{y}} Q_{y}(t, z) \ldots \ldots \ldots \ldots \ldots \ldots
\end{aligned}
$$

(16) 式中, $\eta \in[0,1]$ は学習率を表すパラメータである。 また，上式は $(12)$ 式の割引率を $\gamma=1$ としたものに相当 する。

Q-Routing を改良したルーティングアルゴリズムに Predictive Q-Routing (Choi, Yeong) ${ }^{(12)}$, ConfidenceBased Q-Routing (Kumar, Miikkulainen) (13) がある。 Predictive Q-Routing（PQ-Routng）では Q 值の更新の 際に, 過去の $\mathrm{Q}$ 值の最小值および $\mathrm{Q}$ 值の時間変化を記録す る。そしてこれらの情報を用いて $\mathrm{Q}$ 值の推定值を求め, ネ クストホップの決定を行う。Confidence-Based Q-Routing (CQ-Routing) では, Q 值の更新の際に「信頼度」（confidence measure）を用いて学習率の調整を行う。これは, 長期間更新されない $\mathrm{Q}$ 值に含まれる誤差がその他の $\mathrm{Q}$ 值 に伝搬することを防ぐために使われる。

PQ-Routing と CQ-Routing のどちらも，Q值の更新式 は基本的に (16) 式と同様である。言い換えると, Q 值に反 映されているのは遅延メトリックだけである。リンクコス トなど，他のメトリックを考慮した QoS ルーティングを行 うことは想定されていない。

\section{QoS ルーティングアルゴリズム QQRA}

〈4・1〉 QQRA の特徵＼cjkstart本節では我々が提案するルー ティングアルゴリズム QQRA（Q-learning QoS Routing Algorithm) について説明する。QQRA はQ-Routing 同様, Q-Learning を用いて経路の決定を行う。報酬 $r(\in[0, \bar{Q}])$ に基づく $\mathrm{Q}$ 值の更新は (16) 式を用い, ネクストホップは 原則として (15) 式に基づいて決定する。

Q-Routing との違いは，Q 值の更新に用いる報酬 $r$ が (18) 式に示す通り, 複数のメトリックから計算されている ことである。

$$
r=r_{w}\left\{c_{w} \frac{C_{x}(t, y)}{C_{x t}}+d_{w} \frac{D_{x}(t, y)}{D_{x t}}+q_{w} \frac{b_{x y}}{l_{x y}}\right\}
$$


(18) 式中, $C_{x}(t, y)$ 拉よび $D_{x}(t, y)$ はそれぞれルー夕 $x$ か ら $y$ を経由して $t$ に向かう経路のコストメトリックならび に遅延メトリックである。 $b_{x y}$ 拉よび $l_{x y}$ は，それぞれリン ク $(x, y)$ の出力キューに格納されているパケットの合計サ イズ，ならびに出力キューのバッファ容量を表す。この二 つのパラメータは，遅延コストを補間するための局所的情 報として使用される。 $C_{x t}$ ならびに $D_{x t}$ は，ノード $x$ から $t$ に向かうトラフイックが満たすべきコストメトリックおよ び遅延メトリックの上限を表す。

(18) 式中の倸数 $c_{w}, d_{w}, q_{w}$ は, 報酬 $r$ を計算する際に 各メトリックのトレードオフを表現するために用いる重み 係数である。これらの重み係数は, リンク $(x, y)$ に輻輳が 発生しているかどうかで值を変化させる。輻輳が発生して いないときの重み係数をそれぞれ $c_{i}, d_{i}, q_{i}$, 発生している 場合はそれぞれ $c_{o}, d_{o}, q_{o}$ に設定する。輻輳発生の有無は， 遅延メトリック $d_{x y}$ が与えられた閾值 $d_{t}$ を超えたかどう かで判定する。

QQRA が持っているその他の特徴として，与えられた QOS 制約条件を満たす経路が 2 つ以上存在する場合，それ らの経路にトラフイックを分配できることが挙げられる。こ れを実現するために，QQRA は方策 $\pi_{x}\left(t, y^{*}\right)$ を以下に示 す確率 $p_{x}\left(t, y^{*}\right)$ によって選択する機能を持つ。

$$
\begin{aligned}
& p_{x}\left(t, y^{*}\right)=\frac{\delta_{x}(t)-Q_{x}\left(t, y^{*}\right)}{(n-1) \cdot \delta_{x}(t)} \ldots \ldots \ldots \ldots \ldots \\
& \delta_{x}(t)=\sum_{y \in N_{x}} Q_{x}(t, y) \ldots \ldots \ldots \ldots \ldots \ldots \ldots
\end{aligned}
$$

(19) 式中， $n$ は QoS 制約条件を満たす経路の数を示す。以 後，(15) 式を用いて経路を決定する方法を「決定論的経路 選択」，(19)(20) 式を用いる方法を「確率論的経路選択」と 呼ぶ。

〈4・2 $\rangle$ QQRA が扱う情報 QQRA を使用するノー ドは定期的に経路情報を交換し，遠く離れたノードへの経 路を求める際に必要なメトリック情報を収集する。ノード $x \in N$ が保持する経路情報はノード $x$ に通知された宛先 ノードの集合 $T_{x}$, ノード $y \in N$ を経由して $t \in N$ に向か う経路の $\mathrm{Q}$ 值 $Q_{x}(t, y)$, コストメトリック $C_{x}(t, y)$, 遅延入 トリック $D_{x}(t, y)$, そして $y$ をネクストホップとして使用 可能かどうかを表すフラグ $S_{x}(t, y)$ の 5 種類である。

$S_{x}(t, y)$ の役割について補足する。これは宛先ノード $t$ へ のネクストホップを決定論的経路選択に基づいて決定する 際に，ノード $y$ を候補として使用するかどうかを示すフラ グである。この值が 0 の時は $y$ を候補に含め, 1 の時は $y$ を候補から除外する。 $S_{x}(t, y)$ はループを含まない経路を 求めるために利用される。具体的にはノード $y$ が宛先 $t$ へ のネクストホップにノード $x$ を使用している場合, $S_{x}(t, y)$ に 1 をセットする。これにより, パケットがノード $x$ と $y$ の間で往復する現象を避けることができる。同時に経路の 上流へ向かう方向への切り替えは, 上流側の経路が変更さ れた場合にのみ発生することが保証される。なお，確率論
Table 1. Contents of reply message

\begin{tabular}{|c|c|c|}
\hline & if $z^{*}=x$ & if $z^{*} \neq x$ \\
\hline$Q_{m}(t)$ & $\min _{z \in N_{y}, z \neq x} Q_{y}(t, z)$ & $Q_{y}\left(t, z^{*}\right)$ \\
\hline$C_{m}(t)$ & $\bar{C}$ & $C_{y}\left(t, z^{*}\right)$ \\
\hline$D_{m}(t)$ & $\bar{D}$ & $D_{y}\left(t, z^{*}\right)$ \\
\hline$S_{m}(t)$ & 1 & 0 \\
\hline
\end{tabular}

的経路選択を行う場合は $S_{x}(t, y)$ の値を無視する。

$\langle 4 \cdot 3\rangle \quad$ メャセジ＼cjkstart各ノードは経路情報を交換する ために，以下に示すメッセージを定期的に送信する。

クエリメッセージ＼cjkstart隣接ノードに対して経路情報を要 求するためのメッセージである。このメッセージには, メッセージを作成したノード $x$ の保持する宛先ノード テーブル $T_{x}$ が記録される。このメッセージを受け取った ノード $y$ は Fig. 1 に示す通り， $T_{y}$ に $T_{x}$ の内容をマージ したのち，次に説明するリプライメッセージの生成と送 信を行う。

リプライメッセージクエリメッセージを受け取った ノード $y$ が返信として, クエリの送信ノード $x$ に対し て自身の保持する経路情報を送信するために用いるメッ セージである。このメッセージには，ノードyの保持する 宛先ノードテーブル $T_{y}$ の他, すべての宛先 $t \in T_{y}$ につ いての経路情報 $Q_{m}(t), C_{m}(t), D_{m}(t), S_{m}(t)$ を載せる。 経路情報の内容は, 宛先 $t$ へのネクストホップ $z^{*}$ がクエ リ送信ノード $x$ と同じであるかどうかに応じて Table 1 の通りに設定される。Table 1 に抒いて $\bar{C}$ および $\bar{D} は$ は, それぞれコストメトリックと遅延メトリックの上限值を 表す。

ノード $x$ は Fig. 1 に示す通り, ノード $y$ から受信した リプライメッセージの内容にしたがって経路情報を更新 する。更新式を以下に示す。

$$
\begin{aligned}
C_{x}(t, y) & \leftarrow C_{m}(t)+c_{x y} . \\
D_{x}(t, y) & \leftarrow D_{m}(t)+d_{x y} \\
S_{x}(t, y) & \leftarrow S_{m}(t) \cdots \cdots
\end{aligned}
$$

$Q_{x}(t, y)$ は (16) 式を用いて更新する。ただし QoS 制 約条件に違反した場合は $Q \leftarrow \bar{Q}$ とする。

更新メッセージリンクがダウンしたなどの理由でネッ トワークトポロジーの変更が発生した場合に，隣接ノー ドに対して新しい経路情報を提供するために用いるメッ セージである。ノード $y$ がノード $x$ に対して送信する更 新メッセージの内容は, リプライメッセージとほとんど同 じである。異なる点は, $T_{y}$ にはトポロジーの変化により 経路が変化した宛先ノードだけが記録されていることと, 更新メッセージには $\mathrm{Q}$ 值が記録されていないことである。

ノード $x$ はノード $y$ からの更新メッセージを受信した 場合, リプライメッセージと同じ方法で経路情報を更新 する。ただし $\mathrm{Q}$ 值の更新には, 最後に受信したリプライ メッセージに記録された $Q_{m}(t)$ を使用する。さらにリプ ライメッセージ受信時の処理と異なり, $\mathrm{Q}$ 值の更新後必 ず経路の再計算を行う。 


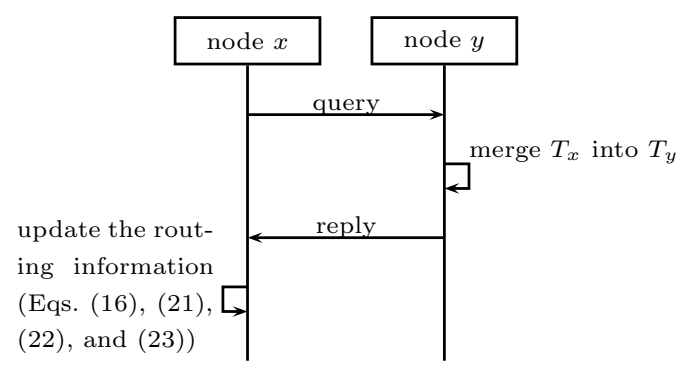

Fig. 1. Sequence diagram of message passing

\section{5. 実験結果と検証}

ルーティングアルゴリズム QQRA の効果を検証するた め，ネットワークシミュレータ $\mathrm{ns} 2^{(14)}$ を用いたシミュレー ションを行った。具体的には QQRA が負荷の変動に伴う通 信遅延変動を検知し, 最大遅延制約と最大コスト制約を満 たす他の経路に切り替えられるかどうかを確認する。同時 に End-to-End の通信遅延のジッタについても検証を行う。

実験結果の比較対象として Shortest Path First Algorithm（以下「SPF」）を用いた。その理由は, SPFが静的 に与えられたリンクコストの合計が最小となる経路を選択 するため，通信遅延の変動による経路の変化が起こらない ことである。これによりネットワークが過負荷であるかど うか，言い換えると輻輳の発生状況を確認できる。本来な らば Chen らのアルゴリズム ${ }^{(5)}$ や Peng のアルゴリズム ${ }^{(6)}$ を比較対象にすべきところである。しかしこれらのアルゴリ ズムは静的な遅延特性を元に経路を検出するアルゴリズム であるため, QoS 制約違反の検出と経路の切り替えという 観点から比較対象にならない。同様にQ-Routing も通信遅 延の推定值である $\mathrm{Q}$ 值に基づいたルーティングを行うため, 最大遅延制約を満たすことを保証しない。さらに遅延メ卜 リックのみに基づくアルゴリズムであるため, Q-Routing も比較対象から除外した。

〈5・1 実験内容＼cjkstart検証に用いたネットワークトポロ ジーを Fig. 2 に示す。このネットワークは, サービスレベ ル契約を結んだ AS （自律システム：同一の運用ポリシー に基づいて管理されるネットワーク）同士で QoS ルーティ ングを行うことを想定している。 AS 同士を接続するエッ ジルータに相当するノードは $R_{01}$ から $R_{05}$ の 5 つとして いる。

Fig. 2 のネットワークにおいて，各リンクの帯域幅は $3.00[\mathrm{Mbps}]$, リンク遅延は $5.00[\mathrm{~ms}]$, コストは 1 である。 Table 2 に実験に用いたトラフイックの設定を示す。QoS 制約条件として, End-to-Endの最大遅延制約に0.5 [s] を, 最大コスト制約に 5 を設定した。 $R_{01}$ から $R_{05}$ の 5 つの ノードはリング状のトポロジーを構成している。したがっ てこれらのノード間にはコストメトリックの異なる 2 つの 経路が存在する。

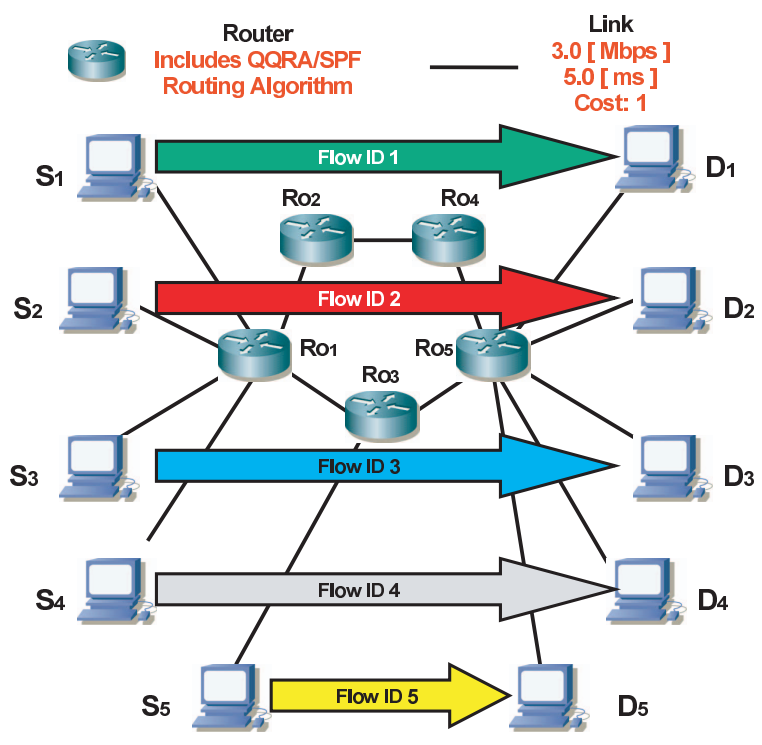

Fig. 2. Network topology

Table 2. Parameter setting for each traffic

\begin{tabular}{|c|c|c|c|c|}
\hline ID & $\begin{array}{c}\text { Traffic } \\
\text { type }\end{array}$ & $\begin{array}{c}\text { Source } \\
\text { node }\end{array}$ & $\begin{array}{c}\text { Destination } \\
\text { node }\end{array}$ & $\begin{array}{c}\text { Input Rate } \\
\text { [Mbps] }\end{array}$ \\
\hline 1 & UDP/CBR & $S_{1}$ & $D_{1}$ & $0.8 / 1.0$ \\
\hline 2 & UDP/CBR & $S_{2}$ & $D_{2}$ & $0.8 / 1.0$ \\
\hline 3 & UDP $/ C B R$ & $S_{3}$ & $D_{3}$ & $0.8 / 1.0$ \\
\hline 4 & UDP/CBR & $S_{4}$ & $D_{4}$ & $0.8 / 1.0$ \\
\hline 5 & UDP $/ C B R$ & $S_{5}$ & $D_{5}$ & $0.8 / 1.0$ \\
\hline
\end{tabular}

Table 3. Parameters settings for QQRA

\begin{tabular}{|c|c||c|c|}
\hline Parameter & Value & Parameter & Value \\
\hline $\bar{Q}$ & $10^{4}$ & $\eta$ & 0.8 \\
\hline$r_{w}$ & $10^{3}$ & $d_{t}$ & $100[\mathrm{~ms}]$ \\
\hline$c_{i}$ & 0.05 & $c_{o}$ & 0.05 \\
\hline$d_{i}$ & 0.20 & $d_{o}$ & 0.45 \\
\hline$q_{i}$ & 0.25 & $q_{o}$ & 0.50 \\
\hline
\end{tabular}

Fig. 2 からわかる通り, SPFを用いて経路を求める場合, Flow ID 5 以外のフローはコストメトリックが最小となる 経路（ $\left.R_{01}, R_{03}, R_{05}\right)$ を必ず使用する。したがって，5つ のフロー全ての合計入カレート（総入カレート）がリンク の通信带域 3.0 [Mbps] に近づくにつれて通信負荷が増大し, 転送遅延の増大と輻輳が発生する。この時 Fig. 2 のエッジ ルータ群が QoS 制約条件を満たす経路, 特に最大通信遅延 制約を満たす経路 $\left(R_{01}, R_{02}, R_{04}, R_{05}\right)$ に切り替えられ るかどうかを確認する。また反対に, 経路 $\left(R_{01}, R_{02}, R_{04}\right.$, $\left.R_{05}\right)$ が QoS 制約条件に違反した場合にも経路 $\left(R_{01}, R_{03}\right.$, $R_{05}$ ）に切り替えられるかどうかもあわせて検証する。

QQRA の学習に用いたパラメータを Table 3 に示す。ク エリメッセージの送信間隔 $T_{i}$ は $100[\mathrm{~ms}]$ とする。また, 経 路決定方法の違いによる比較を行うため, 決定論的経路選 択と確率論的経路選択の両方について実験を行った。

〈5・2〉 遅延制約Ｆig. 3 に総入力レートが 4.0 [Mbps] （各フローの入カレートが $0.8[\mathrm{Mbps}]$ ）における, Flow ID 1 の End-to-End の通信遅延の変化の様子を示す。Fig. 3 (a) 


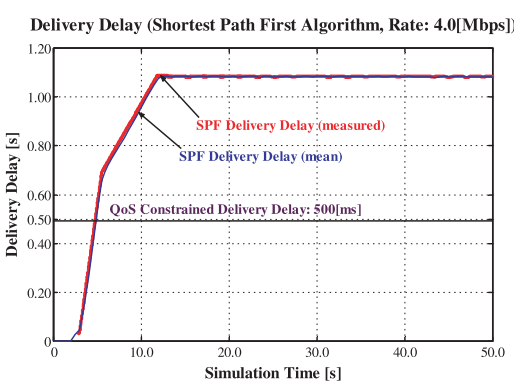

(a) SPF algorithm

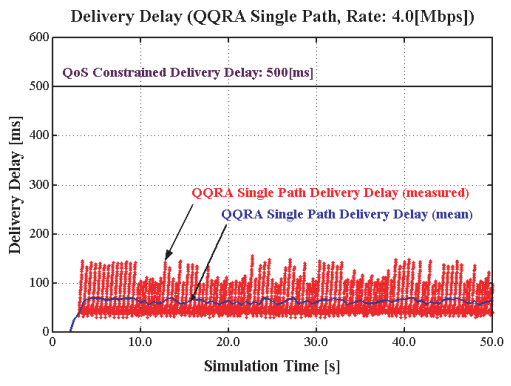

(b) QQRA deterministic mode

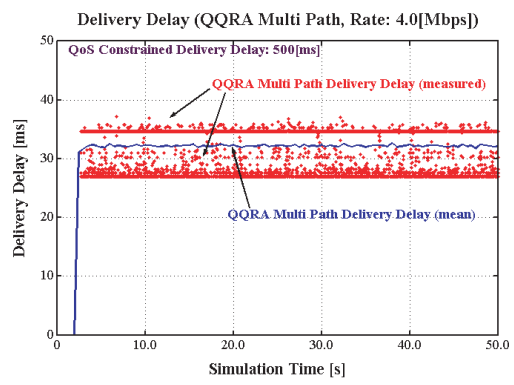

(c) QQRA probabilistic mode

Fig. 3. Communication delay of Flow ID 1 (Total Input Rate: 4.0 [Mbps])

より, SPF アルゴリズムでは総入カレートが経路の带域 3.0 [Mbps] を超えたために輻輳が発生し, その結果遅延制約 $0.5[\mathrm{~s}]$ に違反していることがわかる。それに対してQQRA では決定論的・確率論的の両方とも, 輻輳が発生する前に 経路を切り替えることで遅延制約を満たしていることがわ かる。

Fig. 4 に総入力レートを 5.0 [Mbps]（各フローの入カレー トが $1.0[\mathrm{Mbps}]$ ）にした場合の, Flow ID 1 の End-to-End の通信遅延の変化の様子を示す。SPF アルゴリズムを用い た場合，輻輳が激しくなったために大量のパケット損失が 発生していることがわかる。それに対して QQRA では決 定論的・確率論的の両方とも, 全体的な通信遅延とジッ夕 が増大していることが確認できるが，パケットの損失は発 生していない。

決定論的経路選択と確率論的経路選択の結果に注目した 場合, Fig. 3(b)(c), Fig. 4(b)(c) が示す通り, 平均通信遅 延は確率論的経路選択の方が優れていることがわかる。ま た，ジッタの大きさも確率論的経路選択の方が抑えられて いる。決定論的経路選択では，次の経路更新が行われるま では一つの経路を使いつづける。それに対して確率論的経

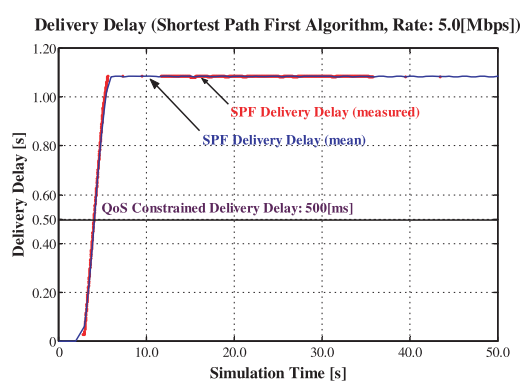

(a) SPF algorithm

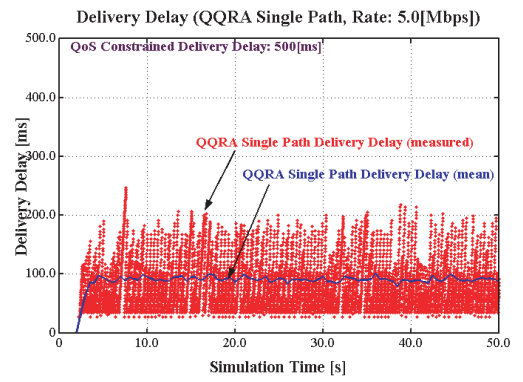

(b) QQRA deterministic mode

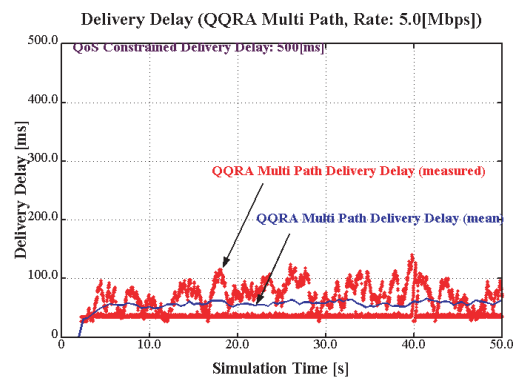

(c) QQRA probabilistic mode

Fig. 4. Communication delay of Flow ID 1 (Total Input Rate: 5.0 [Mbps])

路選択ではパケットごとに経路を切り替える。そのためパ ケットが各経路に分散し，リンクの送信キューにたまるパ ケット数が少なくなることから, 経路中の各ノードに扔け る送信待ち時間が減少したと推測される。しかしながら，経 路の切り替えはリンクの負荷の違いによるキューイング遅 延の変動につながるため, それに伴うジッ夕の発生を抑制 することは困難である。Fig. 3 と Fig. 4 を比較すると，流 入するトラフィックの量が大きくなったときに，ジッタが 顕著に現れることがわかる。

〈5・3〉 コスト制約＼cjkstart次にフローを送信する際に使用 する経路のコストについて評価を行う。Fig. 5 と Fig. 6 は それぞれ総入力レートが $4.0[\mathrm{Mbps}], 5.0[\mathrm{Mbps}]$ における Flow ID 1 の配送に用いた経路のコスト変動を示している。 これらの図から分かる通り, コスト制約条件である 5 以下 のコストメトリックを持つ経路を常に選択していることが 分かる。ここでFig. 5 (b), およびFig. 6 (b) が示している, 確率論的経路選択を用いた場合の結果に注目する。決定論 的経路選択と異なり，確率論的経路選択を用いた場合は $\mathrm{Q}$ 值が最小でない経路に対応するネクストホップを選択する 可能性がある。そのため配送経路中にループが発生するこ 


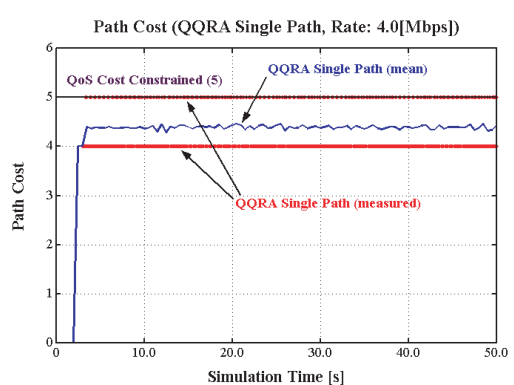

(a) QQRA deterministic mode

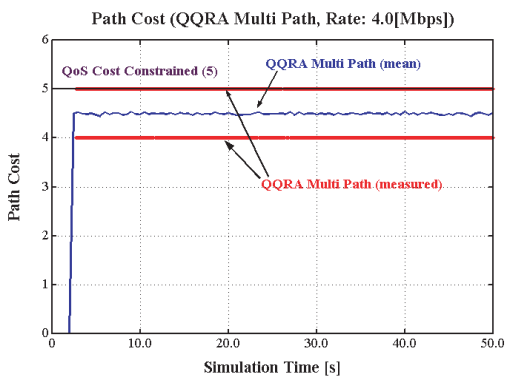

(b) QQRA probabilistic mode

Fig. 5. Cost of route for Flow ID 1 (Total Input Rate: $4.0[\mathrm{Mbps}])$

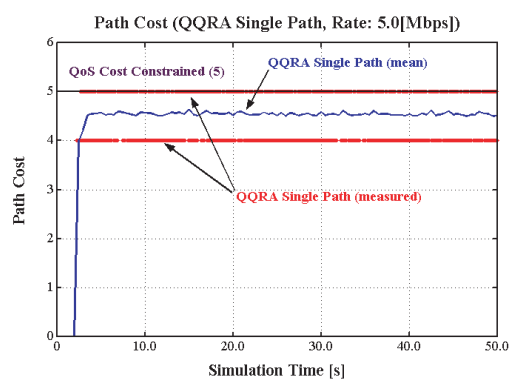

(a) QQRA deterministic mode

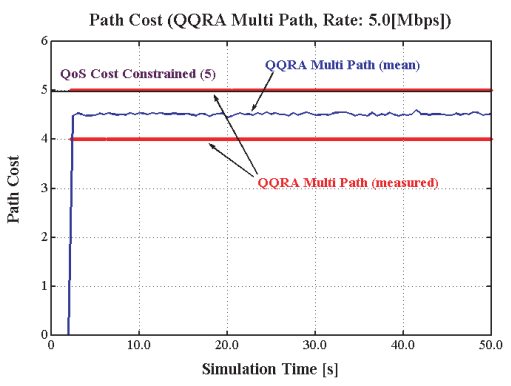

(b) QQRA probabilistic mode

Fig. 6. Cost of route for Flow ID 1 (Total Input Rate: $5.0[\mathrm{Mbps}])$

とがありうる。しかし Fig. 2 よりノード $S_{1}$ と $D_{1}$ の間の 最小コストは 4 である。もし Flow ID 1 のパケットが通過 した経路にループが存在するならば，その経路のコストは 6 以上となる。このため, コスト制約条件を満たすことは 配送経路中にループが発生しないことと等価である。した がってこの結果は, 確率論的経路選択を用いた場合でも配 送ループが発生していないことを示す。

\section{6. まとめ}

本稿では，コストと通信遅延という 2 つのメトリックに 関する QoS 制約条件を満たす経路を発見するための QoS ルーティングアルゴリズム QQRA を提案し, 有効性の検 証を行った。その結果, QQRA では複数のメトリックに基 づく報酬を元にQ-Learningによる学習を行うことで，通 信遅延の変動の検出と QoS 制約条件を満たす別の経路へ の切り替えが可能であることがわかった。さらに確率論的 経路選択により，QOS 制約条件を満たす複数の経路にトラ フィックを分配できることも示した。これを IntServ ${ }^{(16)}$ と 連動させることによって，フローごとに独立した経路を割 り当てるなど, より柔軟な $\mathrm{QOS}$ 制御が行えることが期待で きる。

今後の課題としては, 経路切り替えによって発生するジッ 夕を小さくすることが挙げられる。原理上ジッタの発生を 完全に抑制することはできないが，フローごとに経路を割 り当てたり, 経路ごとのトラフィックの分配率を制御する ことでジッ夕を小さくできると考えられる。また，規模の 大きいネットワークにおいて最大コスト制約に比べて Endto-Endの経路の最小コストがとても小さい場合, 確率論 的経路選択を用いても配送ループが発生しないのかどうか の検証が必要である。もし確率論的経路選択において配送 ループが発生する場合, 学習アルゴリズムの調整を行う以 外にも経路選択の際に IP ヘッダのタイムスタンプオプショ ン (15)，あるいは遅延制約などを記述するための独自のオプ ションを導入し，これらを利用して配送ループの排除を行 うことも視野に入れる必要がある。

謝 辞

本研究を行うにあたって多大なるご支援を賜りました，日 本コムシス（株）の棟方雅之氏に深く感謝いたします。

(平成 21 年 10 月 22 日受付, 平成 22 年 3 月 17 日再受付)

\section{文献}

(1) A. Parekh and R. Gallager: "A Generalized Processor Sharing Approach to Flow Control in Integrated Services Networks - the Single Node Case", IEEE/ACM Trans. Networking, Vol.1, No.3, pp.344-357 (1993)

（2）戸田 巌：「詳解 ネットワーク QoS 技術」, pp.16-65, 103-119, 178-237, オーム社 (2001)

(3) S. Chen and K. Nahrstedt: "An Overview of Quality-ofService Routing for the Next Generation High-Speed Networks: Problems and Solutions", IEEE Network Special Issue on Transmission and Distribution of Digital Video, Vol.12, No.6, pp.64-79 (1998)

(4) Leland et al: "On the Self-Similar Nature of Ethernet Traffic (Extended Version)", IEEE/ACM Trans. Networking, Vol.2, No.1, pp.1-15 (1994)

(5) S. Chen and K. Nahrstedt: "Distributed QoS Routing", Technical report, Department of Computer Science, University of Illinois at Urbana-Champaign (1997)

(6) C. Peng: "Optimization Algorithms for Fault-tolerant and QoS Routing in Networks", PhD Thesis in School of Information Science, Japan Advanced Institute of Science and Technology (2006)

(7) C.J.C.H. Watkins and P. Dayan: "Technical Note Q- 
Learning", Machine Learning, Vol.8, pp.279-292 (1992)

(8) F. Qian and H. Hirata: "A New Distributed QoS Routing Algorithm using Mean Field Approximation Method", IEE

Trans. Electronics, Information and Systems, Vol.127, No.1, pp.59-67 (2007-1) (In Japanese)

銭飛・平田廣則：「平均場近似計算法を用いた分散型 QoS ルーティ ングアルゴリズム」, 電学論 C, 127, 1, pp.59-67 (2007-1)

(9) J. Moy: "OSPF version 2", STD 54, RFC 2178 (1998)

(10) R.S. Sutton and A.G. Barto: "Reinforcement Learning: An Introduction", The MIT Press (1998) (in Japanese) 水上貞芳 - 皆川雅章 共訳 : 「強化学習」, 森北出版 $(2000)$

(11) M.L. Littman and J.A. Boyan: "A Distributed Reinforcement Learning Scheme for Network Routing", Technical Report CMU-CS-93-165, Carnegie Mellon (1993)

(12) S.P.M. Choi and D.Y. Yeung: "Predictive Q-Routing: A Memory-Based Reinforcement Learning Approach to Adaptive Traffic Control", In Advances in Neural Information Processing Systems 8, pp.945-951 (1995)

(13) S. Kumar and R. Miikkulainen: "Confidence-Based QRouting: An On-line Adaptive Network Routing Algorithm", In International Joint Conference on Artificial Intelligence, pp.758-763 (1999)

(14) "The Network Simulator — ns-2", VINT project.

(15) John Postel (ed.): "Internet Protocol" STD 5, RFC 791 (1981)

(16) B. Braden, D. Clark, and S. Shenker: "Integrated Services in the Internet Architecture: an Overview", RFC 1633 (1994)

鵜 根 弘 行 (正員) 1995 年広島大学大学院工学研究科博士課

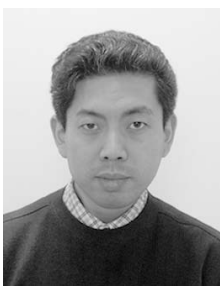
程前期情報工学専攻修了。同年広島国際学院大学 工学部メディア情報通信学科（旧称広島電機大学 電子工学科) 助手に着任。その後 2003 年同講師, 2004 年同情報学部情報デザイン学科講師, 2006 年 4 月千葉大学大学院自然科学研究科人工システ ム科学専攻博士課程後期に在職のまま入学, 2008 年広島国際学院大学情報デザイン学部情報デザイ ン学科講師となり, 現在に至る。コンピュータネットワークなどの並 列分散システムに関する研究に従事。電子情報通信学会会員。

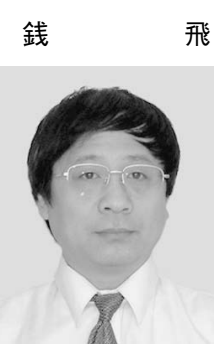

飛（正員） 1991 年千葉大学大学院自然科学研究科 博士課程修了。同年広島国際学院大学電子工学科 講師, 1995 年同情報工学科助教授, 2000 年同教 授, 2004 年関東学院大学工学部電気電子情報工 学科教授となり現在に至る。Ph.D.。学習オート マトンの基本理論, 大規模システムのモデリング, 解析, およびコンピュータネットワーク，ニュー ロコンピュータなどの分散システムの基礎理論の 研究に従事。IEEE, 情報処理学会, 計測自動制御学会, 電子情報通 信学会各会員。

平 田 廣 則 (上級会員) 1976 年東京工業大学大学院電気工

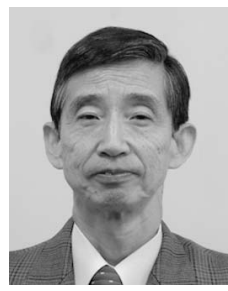
学専攻博士課程修了。同年千葉大学工学部助手, 1981 年同助教授, 1994 年同教授, 1997 年同大 学院自然科学研究科教授, 2007 年同大学院工学 研究科教授となり現在に至る。大規模システムの モデリング, 解析と設計, 特に生態システム, な どに興味を持つ。工学博士。2001 年電気学会業 績賞受賞。IEEE (Fellow), INNS, 電子情報通 信学会, 情報処理学会, 計測自動制御学会, システム制御情報学会, 人工知能学会, 日本数理生物学会各会員。 